\title{
Why the federal government must lead in health care
}

\author{
Matthew B. Stanbrook MD PhD
}

CMAJ Podcasts: editor's summary at soundcloud.com/cmajpodcasts/150896-edit

$\mathrm{F}$ or much of the last decade, Canadian federal health policy has been conspicuous by its absence. During that time, the federal government has walked away from collaborating with the provinces through the Council of the Federation and declined to renew the First Ministers' Accord on Health Care; dithered on public health measures of glaringly obvious benefit, such as tobacco control and asbestos elimination; ignored and disbanded expert advisory panels on health issues; weakened the authority of the public health agency; muzzled scientists; eliminated the long form census, the best source of information on regional disparities relevant to health; and eroded research support, while increasingly tying what remains to business interests rather than health benefits.

By all appearances, the federal government seems to be trying to get itself out of the health care business. It cannot. Many essential aspects of health care are a federal responsibility, and our biggest, most complex problems in the health care system cannot be solved without federal leadership. Without such leadership, Canadians will continue to suffer.

The most important determinants of health, yet the most challenging to address, are socioeconomic. Reversing socioeconomic health consequences can only be done with national leadership and investment in effective social and public health programs. We have done this in decades past - the introduction of medicare is perhaps the most salient example. Yet, recent years have seen Canada's health care system race to the bottom of quality rankings compared with peer nations that have prudently invested in maintaining a strong social safety net. Currently, among countries in the Organisation for Economic Cooperation and Development, only the United States ranks lower. ${ }^{1}$ These rankings highlight both what can be done where the will exists and Canada's embarrassing failure to do it.

Lack of universal drug insurance places at risk the lives and health of far too many Canadians who cannot afford the increasingly expensive medications they need. Evidence published in CMAJ shows that national pharmacare could be implemented with little to no added cost and substantial benefit. ${ }^{2}$ The now defunct health accord pledged to address this gap, yet the federal government did nothing. The provinces have recently made progress on collaborating on a bulk drug purchasing arrangement - which the federal government is now, ironically, insisting it should join. ${ }^{3}$ However, the arrangement falls well short of the savings and health benefits that could be achieved through a truly national formulary available to all Canadians.

Although the Canada Health Act was supposed to guarantee equitable access to health care, Canadians have highly variable access to primary care, seniors' care, mental health care and novel treatments for cancers or rare diseases. Focused national strategies could make real strides toward addressing such problems, which are too big for many provinces to effectively cope with on their own. Instead, the federal government has reformulated transfer payments without any levers to incentivize health equity and national standards, while explicitly tying health care funding to the economy, possibly robbing provinces of future resources exactly when Canadians will need them most.

Protecting and maintaining public health and ensuring the safety and quality of medications are undisputed federal roles in health care. So are providing health care coverage and services to Aboriginal Canadians, refugees, military personnel and inmates of federal prisons. Yet in recent years, the federal government has neglected these responsibilities, even when courts have ordered them to do otherwise.

We cannot solve Canadian health problems without Canadian research to address pressing clinical and policy questions. Yet, federal research funding through agencies such as the Canadian Institutes of Health Research has faced substantial cuts. Of great concern is the change in the federal philosophy behind funding - areas that are more aligned with business interests are increasingly favoured. No matter how fruitful such partnerships might prove, science and health must never be relegated to being secondary means to an economic end.

Too often, at election time, we neglect our health care concerns and let economic fears dominate how we vote. This must change, immediately. CMAJ calls on all Canadians to make sure that health care is a key issue in the upcoming federal election. CMAJ expects all federal political parties to articulate clear, effective, thoughtful policy platforms on health, and advises all Canadians to keep the health policies of their candidates' parties in mind when casting their ballots. Otherwise, we will continue to lack solutions for our urgent health care problems.

\section{References}

1. Davis K, Stremikis K, Squires D, et al. Mirror, mirror on the wall, 2014 update: how the US health care system compares internationally. Washington: The Commonwealth Fund; 2014. Available: www.commonwealthfund.org/ /media/files/publications/ fund-report/2014/jun/1755_davis_mirror_mirror_2014_exec_summ.pdf (accessed 2015 July 28$)$.

2. Morgan SG, Law M, Daw JR, et al. Estimated cost of universal public coverage of prescription drugs in Canada. CMAJ 2015;187:491-7.

3. Kirkup K. BC, Ontario support feds' plea to tackle prescription drug costs. Canadian Press 2015 July 15. Available: www.ctvnews.ca/health/b-c-ontario-support -feds-plea-to-tackle-prescription-drug-costs-1.2469834 (accessed 2015 July 28).

Competing interests: See www.cmaj.ca/site/misc/cmaj_staff.xhtml

Affiliation: Deputy Editor, CMAJ

Correspondence to: $C M A J$ editor, pubs@cmaj.ca

CMAJ 2015. DOI:10.1503/cmaj.150896 